\title{
The effect of disinfectants on Clavibacter michiganensis subsp. sepedonicus and Erwinia carotovora subsp. atroseptica on different surface materials
}

\author{
Hilkka Koponen, MerJa Manninen, PirkKo HarJu, Hanna \\ AVIKAINEN and RISTO TAHVONEN
}

\begin{abstract}
Koponen, H., Manninen, M., Harju, P., Avikainen, H. \& Tahvonen, R. 1992. The effect of disinfectants on Clavibacter michiganensis subsp. sepedonicus and Erwinia carotovora subsp. atroseptica on different surface materials. Agric. Sci. Finl. 1:597602. (Dept. Pl. Biol., P. O. Box 28, SF-00014 University of Helsinki, Finland, Techn. Res. Centre of Finland, Food Res. Lab., SF-02151 Espoo, Finland and Agric. Res. Centre of Finland, Inst. PI. Protect., SF-31600, Jokioinen, Finland.)

The effect of seven disinfectants on Clavibacter michiganensis subsp. sepedonicus and Erwinia carotovora subsp. atroseptica was tested on metal, plastic and wood surfaces in laboratory trials. Iobac $\mathrm{P}$ was the most effective disinfectant in the control of $E$. carotovora on clean and dirty surfaces. Ipasept and Menno-Ter-forte were effective on plastic surfaces, but dirt reduced their efficacy. The least effective preparations were Deskem-1, Virkon S and Korsolin.

Iobac $\mathrm{P}$, Korsolin and Virkon $\mathrm{S}$ were the most effective disinfectants against $C$. michiganensis. The efficacy of Ipasept and Menno-Ter-forte was reduced by dirt. The least effective preparation was Deskem-1.
\end{abstract}

Key words: disinfection, bacterial diseases of potato, organic material, potato black leg, potato ring rot

\section{Introduction}

Bacterial ring rot of potatoes, caused by the bacterium Clavibacter michiganensis subsp. sepedonicus (BRADBURY 1986), has caused sporadic but destructive outbreaks of bacterial ring rot of potatoes. The black leg disease, caused by Erwinia carotovora subsp. atroseptica (BRADBURY 1986), has been a major problem in seed potato production in Finland during the past few years. Bacterial ring rot and black leg disease outbreaks are the result from the use of infected seed potatoes, the bacteria being spread from diseased to healthy seed tubers during planting.

Many chemicals have been recommended for the disinfection of storages, equipment and other surfaces contamined by C. michiganensis subsp. sepedonicus and E. carotovora subsp. atroseptica (DYKSTRA 1941, KNORR 1947, MACLACHLAN 1960, LeTAL 1977, SECOR et al. 1988). Secondary infection of $C$. michiganensis subsp. sepedonicus on infested surfaces and equipment can be effectively eliminated by quaternary ammonium or iodine based compounds (SECOR et al. 1988). Quater- 
nary ammonium solutions have been used extensively in the potato industry for the disinfection of materials, equipment and storages that are used in the handling of potatoes.

Since the control of E. carotovora subsp. atroseptica and $C$. michiganensis subsp. sepedonicus depends on preventing reinfection, it is essential that we have effective bacterial disinfectants at our disposal.

The present experiment was designed to determine the efficacy of some disinfectants against the ring rot and black leg organisms with and withouth organic material on wood, metal and plastic surfaces of equipment and materials used in the handling of seed potatoes.

\section{Material and methods}

Seven disinfectants (Table 1) were tested against bacterial diseases using the concentrations recommended by the manufacturer. The disinfectants were diluted in saline.

One-to two-day old cultures of Clavibacter michiganensis subsp. sepedonicus (NCPPB 2137) and Erwinia carotovora subsp. atroseptica (NCPPB 549) obtained from the National Collec-

Table 1. The disinfectants tested for control of bacterial diseases.

\begin{tabular}{llc}
\hline Disinfectant & Active ingredient \% & $\begin{array}{c}\text { Tested } \\
\text { concentration } \\
\%\end{array}$ \\
\hline Deskem-1 & $\begin{array}{l}\text { Quaternary ammonium } \\
\text { compounds, 20.0 }\end{array}$ & 0.2 \\
Iobac P & $\begin{array}{l}\text { Iodine, 1.8 } \\
\text { Quasept }\end{array}$ & 3.0 \\
Korsolin & $\begin{array}{l}\text { Gompounds, 2.8 } \\
\text { Menno-Ter-Forte }\end{array}$ & $\begin{array}{l}\text { Quaternary ammonium } \\
\text { compounds, 32.5 }\end{array}$ \\
$\begin{array}{ll}\text { Sodium hypochlo- } \\
\text { rite (NaOClive chlorine, 10.0 } \\
\text { Virkon S }\end{array}$ & $\begin{array}{l}\text { Potassium } \\
\text { peroxysulphate, 60.0 }\end{array}$ & 1.0 \\
& & 10.0 \\
\hline
\end{tabular}

tion of Plant Pathogenic Bacteria, England, were used.

The surface materials, stainless steel (AISI 316), polyethene plastic and pine wood discs of a diameter of approx. $1 \mathrm{~cm}$, were sterilized by autoclaving. The discs were transferred aseptically onto 24 hole Limbro plates. The plastic and wood discs were fixed onto the bottom of the plates using sterile adhesive material.

The organic material used was a mull-peat mixture. One gram of mull-peat was mixed in $50 \mathrm{ml}$ of saline and autoclaved. The discs were contaminated by applying $2 \mathrm{ml}$ of the mull-peat mixture to the holes. The organic material was allowed to sediment on the surface of the discs. The extra fluid was removed from all holes aseptically with a Pasteur's pipette, and the plates with the discs were dried in an incubation chamber at $+30^{\circ} \mathrm{C}$ with the lid slightly open.

E. carotovora subsp. atroseptica was grown in Erwinia LB broth (tryptone $10 \mathrm{~g}$, yeast extract $5 \mathrm{~g}$, $\mathrm{NaCl} 10 \mathrm{~g}, \mathrm{H} 2 \mathrm{O} 1000 \mathrm{ml}$ ) for one day at $+25^{\circ} \mathrm{C}$. The bacterial suspensions were diluted in fresh growth medium (1:10). Diluted bacterial suspension $(70 \mu \mathrm{l})$ was added onto the surface of the discs. The drops containing bacteria were allowed to stand at room temperature overnight (metal and plastic) or for $15 \mathrm{~min}$ (wood). The wood discs were tested on the same day the bacterial suspension had been applied. Any fluid remaining on the surface of the metal and plastic discs was removed by drying them in incubators $\left(+30^{\circ} \mathrm{C}\right)$.

If a sufficient number of bacteria was not obtained by allowing the drops to stand on the surface, $2 \mathrm{ml}$ of bacterial suspension (1:10 in fresh growth medium) was added into each hole and allowed to stand overnight at $+25^{\circ} \mathrm{C}$. The fluid was removed from the holes and bacteria were added once more and allowed to stand. Thereafter the discs were dried.

The disinfection efficacy was tested at room temperature. Two $\mathrm{ml}$ of disinfection suspension or saline (control) was pipetted in the holes so that the disc surfaces containing bacteria remained under 
the fluid. The test was made with three replicates and it was repeated three times.

The disinfectant was allowed to act for $20 \mathrm{~min}$, whereafter the fluid was removed and the discs were placed into tubes containing $1.5 \mathrm{ml}$ of inactivation solution (lecithin $1.5 \mathrm{~g}$, Tween $8018 \mathrm{ml}$, L-histidine $0.5 \mathrm{~g}$, Na-thiosulphate $4 \mathrm{~g}, 0.25 \mathrm{~N}$ phosphate buffer ( $\mathrm{pH} 7.2) 5 \mathrm{ml}$ and $\mathrm{H} 2 \mathrm{O} 500 \mathrm{ml}$ ) for 5 min to inactivate the disinfectant. The bacteria and organic material possibly occurring on the surface of the discs were removed with cottonwool swabs. The bacterial count of the suspension was determined by surface cultures on agar plates. E. carotovora subsp. atroseptica was cultured on nutrient agar plates (Difco); the plates were incubated for 3-4 days at $+25^{\circ}$ C. C. michiganensis subsp. sepedonicus was cultured on yeast glucose mineral oil agar (LELLIOTT and STEAD 1987) and incubated for 6-7 days at $+25^{\circ} \mathrm{C}$. The trial consisted of three replicates and it was repeated three times. Virkon $\mathrm{S}$ was not tested at the same time as the other disinfectants, but the same test methods were applied.

The efficacy percentage of disinfectant on bacteria was calculated using the formula:

$$
\frac{(N c-N d) * 100}{N c}
$$

where $\mathrm{Nc}$ was the number of colony forming units developed in the control series in which the disinfectant was replaced by saline, and $\mathrm{Nd}$ was the number of colony-forming units counted after exposure to the disinfectant. The values are means of three replications.

\section{Results}

Iobac $\mathrm{P}$ was the most effective preparation in the control of Erwinia carotovora subsp. atroseptica on dirty and clean metal, plastic and wood surfaces. Menno-Ter-forte was effective on plastic surfaces, but organic material reduced its efficiency. Deskem-1 was the least effective on all surfaces. Also
Virkon S (1\%) and Korsolin were ineffective on all surface materials against $E$. carotovora subsp. atroseptica. Of the surface materials used, plastic was the easiest to disinfest (Table 2).

Clavibacter michiganensis subsp. sepedonicus was more susceptible to the disinfectants than $E$. carotovora subsp. atroseptica. Iobac P, Ipasept, Korsolin, Menno-Ter-forte and Virkon S were effective in the control of $C$. michiganensis subsp. sepedonicus on metal and plastic surfaces. Organic material impaired the efficiency of Ipasept and Menno-Ter-forte. The wood surface was more difficult to disinfest than metal and plastic surfaces. Korsolin, $\mathrm{NaOCl}$ and Virkon $\mathrm{S}$ were the most effective disinfectants on wood surface against $C$. michiganensis subsp. sepedonicus on clean and dirty surfaces. The organic material did not reduce the efficacy of Korsolin, $\mathrm{NaOCl}$ and Virkon S. The least effective disinfectant was Deskem-1 (Table 2).

\section{Discussion}

Iobac P was effective in the control of both Clavibacter michiganensis subsp. sepedonicus and Erwinia carotovora subsp. atroseptica on plastic, metal and wood surfaces. Iobac $\mathrm{P}$ has been shown also in previous studies very effective in the control of $C$. michiganensis subsp. sepedonicus (DINESEN 1984, BÅNG 1987) and E. carotovora subsp. atroseptica (BÅNG 1987).

Korsolin was effective against $C$. michiganensis subsp. sepedonicus, but the effect was not satisfactory enough against $E$. carotovora subsp. atroseptica. According to DINESEN (1984), too, the efficacy of Korsolin (2\%) is good against C. michiganensis subsp. sepedonicus when the exposure time is at least $10 \mathrm{~min}$.

In the present study, Menno-Ter-forte was poorly effective against $E$. carotovora subsp. atrosepti$c a$, but effective against $C$. michiganensis subsp. sepedonicus. These results are consistent with previous data (BÅNG 1987). 
Table 2. The effect of disinfectants against Erwinia carotovora subsp. atroseptica (E) and Clavibacter michiganensis subsp. sepedonicus $(\mathrm{C})$ on clean and dirty metal, plastic and wood surfaces

\begin{tabular}{|c|c|c|c|c|c|c|}
\hline \multirow{2}{*}{$\begin{array}{l}\text { Surface } \\
\text { material }\end{array}$} & \multirow[t]{2}{*}{ Disinfectant } & \multirow{2}{*}{$\begin{array}{c}\text { Concentration } \\
\%\end{array}$} & \multicolumn{2}{|c|}{ Clean } & \multicolumn{2}{|c|}{ Dirty } \\
\hline & & & E & $\bar{C}$ & $\mathrm{E}$ & $\mathrm{C}$ \\
\hline & & \multicolumn{5}{|c|}{ Efficiency \% } \\
\hline \multirow{7}{*}{ Metal } & Deskem-1 & 0.2 & 11 & 74 & 0 & 10 \\
\hline & Iobac P & 3 & 82 & 100 & 88 & 100 \\
\hline & Ipasept & 2 & 63 & 100 & 0 & 35 \\
\hline & Korsolin & 3 & 4 & 100 & 28 & 100 \\
\hline & Menno-Ter-forte & 1 & 38 & 100 & 23 & 46 \\
\hline & $\mathrm{NaOCl}$ & 10 & 57 & 66 & 76 & 95 \\
\hline & Virkon S & 1 & 10 & 7 & 38 & 100 \\
\hline \multirow[t]{7}{*}{ Plastic } & Deskem-1 & 0.2 & 0 & 74 & 0 & 2 \\
\hline & Iobac $\mathrm{P}$ & 3 & 100 & 100 & 100 & 100 \\
\hline & Ipasept & 2 & 87 & 100 & 42 & 55 \\
\hline & Korsolin & 3 & 16 & 100 & 22 & 100 \\
\hline & Menno-Ter-forte & 1 & 96 & 100 & 76 & 65 \\
\hline & $\mathrm{NaOCl}$ & 10 & 33 & 65 & 46 & 100 \\
\hline & Virkon S & 1 & 34 & 100 & 3 & 100 \\
\hline \multirow[t]{7}{*}{ Wood } & Deskem-1 & 0.2 & 0 & 12 & 0 & 22 \\
\hline & Iobac P & 3 & 100 & 20 & 100 & 100 \\
\hline & Ipasept & 2 & 59 & 73 & 45 & 10 \\
\hline & Korsolin & 3 & 3 & 100 & 14 & 100 \\
\hline & Menno-Ter-forte & 1 & 44 & 5 & 38 & 19 \\
\hline & $\mathrm{NaOCl}$ & 10 & 23 & 100 & 28 & 90 \\
\hline & Virkon S & 1 & 10 & 100 & 5 & 100 \\
\hline
\end{tabular}

Organic material reduced the efficacy of MennoTer-forte and Ipasept on all the materials investigated, whereas the efficacy of Iobac P was not affected by organic material. Also in other studies organic material has been shown to reduce the efficacy of disinfectants against bacteria (DINESEN and LøSCHENKOHL 1987), the efficacy of $\mathrm{NaOCl}$ and iodine based disinfectants in particular (SECOR et al. 1988). In the present study this was not observed. The differences may be due to the fact that the bacteria were tested in the presence of dry growth medium.

On the basis of this and other studies (LETAL 1977), quaternary ammonium solutions are not suitable for the control of E. carotovora subsp. atroseptica on wood and metal surfaces although these have been earlier recommended for disinfection of black leg bacteria from these surfaces (MACLACHLAN 1960). In this study, quaternary ammo- nium solutions (Ipasept and Menno-Ter-forte) gave good control of $C$. michiganensis subsp. sepedonicus on clean metal and plastic surfaces, but organic material reduced the efficacy of the compounds.

A disinfectant applicable for the control of $E$. carotovora subsp. atroseptica and C. michiganensis subsp. sepedonicus should act also on dirty wood and metal surfaces, because organic material is always present in places where potato is being handled. Based on the data presented here, the use of Iobac P may be applicable for the disinfection of wood, plastic and metal surfaces contamined by $E$. carotovora subsp. atroseptica and $C$. michiganensis subsp. sepedonicus. However, it must be taken into consideration that Iobac P solution is corrosive to metals and an iodine based disinfectant may cause allergic reactions to the user in a confined environment. Korsolin and Virkon $\mathrm{S}$ are also effective and $\mathrm{NaOCl}$ provided complete control against 
C. michiganensis subsp. sepedonicus. Hypochlorite solution is also corrosive to metals, and this must be taken into consideration when used.

Before disinfection the surfaces should be cleaned from mull and plant debris, because organic material reduces the disinfection capacity. These results are based on laboratory tests and before it is posible to recommend any disinfectant for use in practice it should be tested under conditions simulating practical conditions or in the field. Also the method of application should be tested, because it may affect the disinfection capacity.

\section{References}

BÃNG, U. 1987. Försök med desinfektionsmedel. Spor potatisodl. 5, 2: 32-34.

Bradbury, J. F. 1986. Guide to plant pathogenic bacteria. CAB International Mycological Institute. 332 p.

Dinesen, I. G. 1984. Desinfektionsmidlers effekt på Corynebacterium sepedonicum (kartoflens ringbakteriose). Tidsskr. Planteavl 88: 413-415.

— \& Løschenkoht, B. 1987. Desinfektionsmidlers effekt under smudsbelastning. 4. Danske Planteværnskonference. Sygdomme og skadedyr 1987: 93-100.

Dykstra, T. P. 1941. Results of experiment in control of bacterial ring rot of potatoes in 1940. Am. Potato J. 18: 27-55.

KNORR, L. C. 1947. Field testing of disinfectants for the control of potato ring rot bacteria on wooden and metallic surfaces. Am. Potato J. 24: 141-150.

Lellott, R. A. \& Stead, D. E. 1987. Methods for the diagnosis of bacterial diseases of plants. Methods in Plant Pathology. Blackwell Scientific Publications. Oxford. Vol. 2. 216 p.

LetAL, J. R. 1977. Efficacy of disinfectants against potato ring rot and blackleg bacteria. Am. Potato J. 54: 405-409.

Løschenkohl, B., Dinesen, I. G. \& Thinggaard, K. 1990. Afprøving af desinfektionsmidler. Gartn. Tid. 106: 13241325 .
MacLachlan, D. S. 1960. Disinfectants and potato ring rot control. Am. Potato J. 37: 325-337.

Secor, G. A., De Buhr, L. \& Gudmestad, N. C. 1988. Susceptibility of Corynebacterium sepedonicum to desinfectants in vitro. Plant Dis. 72: 585-588.

\section{Manuscript received June 1992}

Hilkka Koponen

Department of Plant Biology

P. O. Box 28

SF-00014 University of Helsinki, Finland

\section{Merja Manninen}

Pirkko Harju

Technical Research Centre of Finland

Food Research Laboratory

SF- 02151 Espoo, Finland

Hanna Avikainen

Risto Tahvonen

Agricultural Research Centre of Finland

Institute of Plant Protection

SF-31600 Jokioinen, Finland 
SELOSTUS

\title{
Desinfiointiaineiden vaikutus Clavibacter michiganensis subsp. sepedonicus ja Erwinia carotovora subsp. atroseptica bakteereihin eri pintamateriaaleilla
}

\author{
HilkKa Koponen, MerJa Manninen, PirkKo HarJu, Hanna \\ AVIKAINEN ja RISTO TAHVONEN
}

Helsingin yliopisto, Valtion teknillinen tutkimuskeskus ja Maatalouden tutkimuskeskus

Seitsemän desinfiointiaineen tehoa testattiin perunan vaalearengasmätä- (Clavibacter michiganensis subsp. sepedonicus) ja perunan tyvimätä- (Erwinia carotovora subsp. atroseptica) bakteereihin liatuilla ja puhtailla metalli-, muovi- ja puupinnoilla laboratoriokokeissa. Testattavat valmisteet olivat Deskem-1, Ipasept ja Menno-Ter-forte (kvartaarisia ammoniumyhdisteitä), Iobac P (jodi), Korsolin (glutaraldehydi ), natriumhypokloriitti (aktiivinen kloori) ja Virkon S (kaliumperoksisulfaatti).

Iobac $\mathrm{P}$ oli tehokkain valmiste $E$. carotovora subsp. atroseptica- bakteeria vastaan likaisilla ja puhtailla metalli-, muovi- ja puupinnoilla. Menno-Ter-forte oli melko tehokas muovipinnoilla, mutta lika heikensi sen tehoa. Deskem-1:n teho oli huonoin kaikilla pinnoilla. Myös 1 \% Virkon $\mathrm{S}$ ja Korsolin tehosivat bakteeriin huonosti. Pintamateriaaleista muovi oli helpoin puhdistaa.

C. michiganensis subsp. sepedonicus oli desinfiointiaineil- le herkempi kuin $E$. carotovora subsp. atroseptica. Iobac P, Ipasept, Korsolin, Menno-Ter-forte ja Virkon S olivat tehokkaita $C$. michiganensis subsp. sepedonicus- bakteeria vastaan metalli- ja muovipinnoilla. Lika heikensi Ipaseptin ja MennoTer-forten tehoa. Puupinta oli vaikeampi puhdistaa kuin metalli- ja muovipinnat. Parhaiten puupinnalla toimivat Korsolin, $\mathrm{NaOCl}$ ja Virkon S. Teholtaan heikoin valmiste oli Deskem-1.

Tehtyjen kokeiden perusteella vaalearengasmatä- ja tyvimätäbakteerien desinfiointiin perunavarastoissa voidaan suositella Iobac P-valmistetta. Sitä käytettäessä tulee ottaa huomioon aineen metalleja (alumiini, kupari, messinki, galvanoitu pelti) syövyttävä vaikutus. Metallipinnat eivät saa olla valmisteen kanssa kosketuksissa yli 20 minuuttia. Korsolin, Virkon $\mathrm{S}$ ja NaOCl-valmisteet soveltuvat vaalearengasmätäbakteerin puhdistukseen. Myös natriumhypokloriitti syövyttää metallipintoja. 